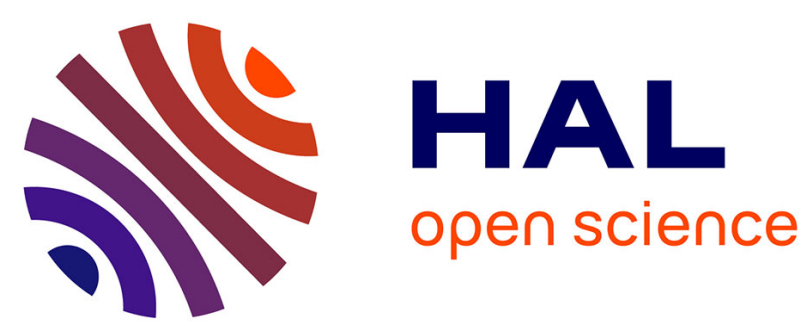

\title{
Synthesis, Characterization, and Antileishmanial Activity of Neutral Gold(I) Complexes with N-heterocyclic Carbene Ligands Bearing Sulfur-Containing Side Arms
}

Soumia Ftouh, Sandra Bourgeade-Delmas, Mohamed Belkadi, Céline Deraeve, Catherine Hemmert, Alexis Valentin, Heinz Gornitzka

\section{To cite this version:}

Soumia Ftouh, Sandra Bourgeade-Delmas, Mohamed Belkadi, Céline Deraeve, Catherine Hemmert, et al.. Synthesis, Characterization, and Antileishmanial Activity of Neutral Gold(I) Complexes with N-heterocyclic Carbene Ligands Bearing Sulfur-Containing Side Arms. Organometallics, 2021, 40 (10), pp.1466-1473. 10.1021/acs.organomet.1c00113 . hal-03233814

\section{HAL Id: hal-03233814 \\ https://hal.science/hal-03233814}

Submitted on 21 Oct 2021

HAL is a multi-disciplinary open access archive for the deposit and dissemination of scientific research documents, whether they are published or not. The documents may come from teaching and research institutions in France or abroad, or from public or private research centers.
L'archive ouverte pluridisciplinaire HAL, est destinée au dépôt et à la diffusion de documents scientifiques de niveau recherche, publiés ou non, émanant des établissements d'enseignement et de recherche français ou étrangers, des laboratoires publics ou privés. 


\title{
Synthesis, characterization and anti-leishmanial activity of neutral gold(I) complexes with $N$-heterocyclic carbene ligands bearing sulfur containing side arms.
}

\author{
Soumia Ftouh ${ }^{\mathrm{a}, \mathrm{b}, \$}$, Sandra Bourgeade-Delmas ${ }^{\mathrm{c}, \$}$, Mohamed Belkadi $^{\mathrm{b}}$, Céline Deraeve ${ }^{\mathrm{a}}$, \\ Catherine Hemmert*, ${ }^{*}$, Alexis Valentin*,c, Heinz Gornitzka*,a \\ ${ }^{a}$ LCC-CNRS, Université de Toulouse, CNRS, UPS, Toulouse, France \\ E-mail: hemmert@1cc-toulouse.fr and gornitzka@1cc-toulouse.fr \\ b (L.S.P.B.E), Département de Génie Chimique, Faculté de Chimie, Université des Sciences et de la Technologie d'Oran \\ Mohamed Boudiaf, USTO-MB, B.P 1505, El Mnaouer, Oran 31000, Algerie. \\ ${ }^{\mathrm{c}}$ UMR 152 PharmaDev, Université de Toulouse, IRD, UPS, Toulouse, France \\ e-mail: alexis.valentin@univ-tlse3.fr \\ $\$$ These authors equally contributed to the work.
}

\begin{abstract}
With an estimated annual incidence of one million cases, leishmaniasis is one of the top five vector-borne diseases. Currently available medical treatments involve side effects, including toxicity, non-specific targeting, and resistance development. Thus, new antileishmanial chemical entities are of the utmost interest to fight against this disease. We have shown in previous studies that gold(I) complexes bearing $N$-heterocyclic carbene (NHC) ligands with nitrogen or sulfur containing side arms have interesting biological activities in the field of cancer, malaria and leishmaniasis. The present study evaluates the in vitro antileishmania effects on L.infantum axenic amastigotes and their cytotoxicity for the human Thp1 cell line of a new family of 6 new imidazolium salts and their corresponding neutral (NHC)Au(I)Cl complexes. All new compounds have been characterized by classical analytical methods and five gold complexes have been evidenced by X-ray structure determination. We showed that one proligand has moderate activity $\left(\mathrm{IC}_{50}=8.24 \mu \mathrm{M}\right)$ while 4 of 6 gold complexes have $\mathrm{IC}_{50}$ values in the $\mu \mathrm{M}$ range $(0.15-1.3 \mu \mathrm{M})$ including 3 with SI's between 46 and 108. These results suggest remarkable leishmanicidal activity in vitro for 3 new neutral (NHC)Au(I)Cl complexes making them candidate for further in vivo studies which are under investigation.
\end{abstract}

\section{INTRODUCTION}

\section{INTRODUCTION}

In its 2018 report WHO classified 20 Neglected Tropical Diseases (NTDs) affecting one billion people in low-income populations in 149 countries. ${ }^{1}$ Among these NTDs, leishmaniasis threatens approximately more than one billion people $^{1}$ mostly in tropical regions (Brazil, India, East Africa) but also in wealthy countries (peculiarly around Mediterranean Sea), even if the most severe cases occur in South America (www.who.int/leishmaniasis/burden/en/). Furthermore, in a global warming context, the sandfly (vector of the illness) area is slowly extending over the Mediterranean seashore in Europe. ${ }^{2}$ These infectious diseases are caused by parasites of the Leishmania genus, which are transmitted to a mammal host (mainly human, dog, monkey, rodent) during the bite of an infected phlebotomine sandfly (Phlebotomus sp./Lutzomilla $s p.)^{3}$ Among several clinical forms of Leishmaniasis, visceral leishmaniasis (VL) is fatal if untreated (about 20-30000 deaths a year worldwide $\left.{ }^{1}\right)$. Leishmaniasis is due to the visceralization of the intracellular amastigote stage of the parasite, especially in liver,spleen and bone marrow, more precisely in mononuclear cells of its vertebrate host. ${ }^{4}$ The two main Leishmania species responsible for VL are $L$. infantum and $L$. donovani. In the absence of an effective human vaccine, the control of leishmaniasis is based on chemotherapy with only few efficient drugs currently available: amphotericin B, miltefosine, antimonial derivatives, pentamidine and paromomycin. These drugs are either expensive (e.g., liposomal amphotericin B), present severe side effects (e.g., the nephrotoxicity of amphotericin $\mathrm{B}$, the teratogenicity of miltefosine) or show an increasing lack of efficacy due to the emergence of resistant parasites (antimony derivatives and miltefosine). ${ }^{5,6}$ Fexinidazole, a 5nitroimidazole, was recently in phase II of clinical trials against VL but showed clearly a lack of efficacy and currently, there is no new chemical molecule in clinical trials at the moment. $^{5}$

A non-classical approach concerns metallo-drugs. Some organometallic compounds have been designed as new drugs for important medical human problems including cancer, bacterial, viral and parasitic diseases. ${ }^{7}$ Some metal based-drugs show promising leishmanicidal activities. $\mathrm{Cu}$ (II), $\mathrm{Ni}$ (II) and $\mathrm{Co}$ (II) triazopyrimidine derivatives were tested in vitro against $L$. 
braziliensis and $L$. infantum amastigotes $\left(\mathrm{IC}_{50}=17.0-40.8\right.$ $\mu \mathrm{M}){ }^{8} \mathrm{Ni}(\mathrm{II})$ thiourea and $\mathrm{Co}(\mathrm{II})$ acyl thiourea complexes showed activities in vitro against $L$. major, with $\mathrm{IC}_{50}$ in the nanomolar range. ${ }^{9,10}$ Cisplatin was active against murine visceral leishmaniasis alone or in association. ${ }^{112}$ The similarity between metabolic pathway of kinetoplastid parasites and tumor cells ${ }^{13}$ and the fact that many antiprotozoal drugs bind to DNA, has led to the use of transition metal complexes as metallointercalators in the context of leishmaniasis. In this field, iridium, ruthenium, gold, copper, platinum and rhodium complexes have shown excellent antileishmanial activities. ${ }^{14-17}$ Among them, $\mathrm{Cu}(\mathrm{II}),{ }^{18,19} \mathrm{Ag}(\mathrm{I}),{ }^{20}$ and $\mathrm{Au}(\mathrm{III})^{21}$ metal complexes with planar organic compounds have shown in vitro activities against the promastigote form of L. braziliensis and L. mexicana. Other series of $\mathrm{Au}(\mathrm{I})$ and $\mathrm{Au}(\mathrm{III})$ complexes have been studied on L. mazonensis and L. braziliensis. ${ }^{22}$

One target for antileishmanial drugs is trypanothione reductase (TR), a crucial redox enzyme in Leishmania. ${ }^{23,24}$ TR contains active-site thiol groups so thiophilic metal-based compounds can potentially serve as selective inhibitors of TR. Gold complexes are proposed to block active site cysteine groups in thiol-dependent enzymes. The antiarthritic gold(I) drug auranofin and $\left[\mathrm{AuCl}\left(\mathrm{PEt}_{3}\right)\right]$ ( $\mathrm{PEt}_{3}$ : triethylphosphine) were tested in vitro as antileishmanial agents and induced a dose dependent antiproliferative effect on promastigotes of $L$. infantum and L. major. ${ }^{25}$ Both auranofin and $\left[\mathrm{AuCl}\left(\mathrm{PEt}_{3}\right)\right]$ cause inhibition of TR with a $\mathrm{Ki}$ of 0.155 and $0.018 \mu \mathrm{M}$, respectively, stronger than antimony(III) compounds. ${ }^{26}$ Moreover, a low-resolution crystal structure of auranofin-TR of $L$. infantum was obtained and the gold center was found to be tightly bound to two cysteine residues in the active site of the enzyme.

In this context we have shown in previous studies that gold(I) complexes bearing $N$-heterocyclic carbene (NHC) ligands with nitrogen or sulfur containing side arms have interesting biological activities in the field of cancer, malaria and leishmaniasis. ${ }^{27-34}$ In this study we present the synthesis, characterization and anti-leishmanial potency of a new family of neutral gold(I)-NHC sulfur containing systems with improved activity against $L$. infantum.

\section{RESULTS AND DISCUSSION}

\section{$\underline{S}$}

Synthesis of substituted imidazoles $\mathbf{1}$ to $\mathbf{3}$. The sulfur containing imidazole derivatives $\mathbf{1}$ to $\mathbf{3}$ were readily obtained by solid state reactions between imidazole and para substituted bromophenyl derivatives, namely 1-bromo-4(methylsulfonyl)benzene, 1-bromo-4-(phenylthio)benzene and 1-bromo-4-[(trifluoromethyl)thio]benzene at $205{ }^{\circ} \mathrm{C}$ in the presence of potassium carbonate and copper sulfate. All three compounds have been characterized by ${ }^{1} \mathrm{H}$ and ${ }^{13} \mathrm{C} \mathrm{NMR}$ spectroscopy, high resolution mass spectrometry and elemental analysis.

Synthesis of imidazolium salts $\mathbf{4}$ to $\mathbf{9}$. For the synthesis of $\mathbf{4}$ to $\mathbf{6}$, benzyl chloride and $\mathbf{1}, \mathbf{2}$ or $\mathbf{3}$ were dissolved in acetonitrile and heated at $80{ }^{\circ} \mathrm{C}$. In the case of 7 to 9 a large excess of 2-bromopropane was added to the substituted imidazole derivatives $\mathbf{1}$ to $\mathbf{3}$ and heated to $80{ }^{\circ} \mathrm{C}$, for $\mathbf{8}$ and $\mathbf{9}$ without an additional solvent and for $\mathbf{7}$ in acetonitrile. All proligands 4 to 9 have been characterized by ${ }^{1} \mathrm{H}$ and ${ }^{13} \mathrm{C}$ NMR spectroscopy, high resolution mass spectrometry and elemental analysis. The most characteristic features are the peaks in the ${ }^{1} \mathrm{H}-\mathrm{NMR}$ spectra of the imidazolium protons $\mathrm{H} 2$ between 10.06 and $11.61 \mathrm{ppm}$.

Synthesis of gold(I) complexes $\mathbf{1 0}$ to $\mathbf{1 5}$. The gold(I) NHC complexes were synthesized using the silver transmetallation route. Complexes $\mathbf{1 0}$ to $\mathbf{1 5}$ have been obtained with high yields from 85 to $98 \%$. All complexes have been characterized by ${ }^{1} \mathrm{H}$ and ${ }^{13} \mathrm{C}$ NMR spectroscopy, by high resolution mass spectrometry and the purity of the complexes has been confirmed by elemental analysis. The most characteristic features are the peaks in the ${ }^{13} \mathrm{C}$ NMR spectra of the carbene carbon atoms C2 between 167 and 170 ppm, typical values for mono-NHC gold(I) complexes of type NHC-Au-Cl.

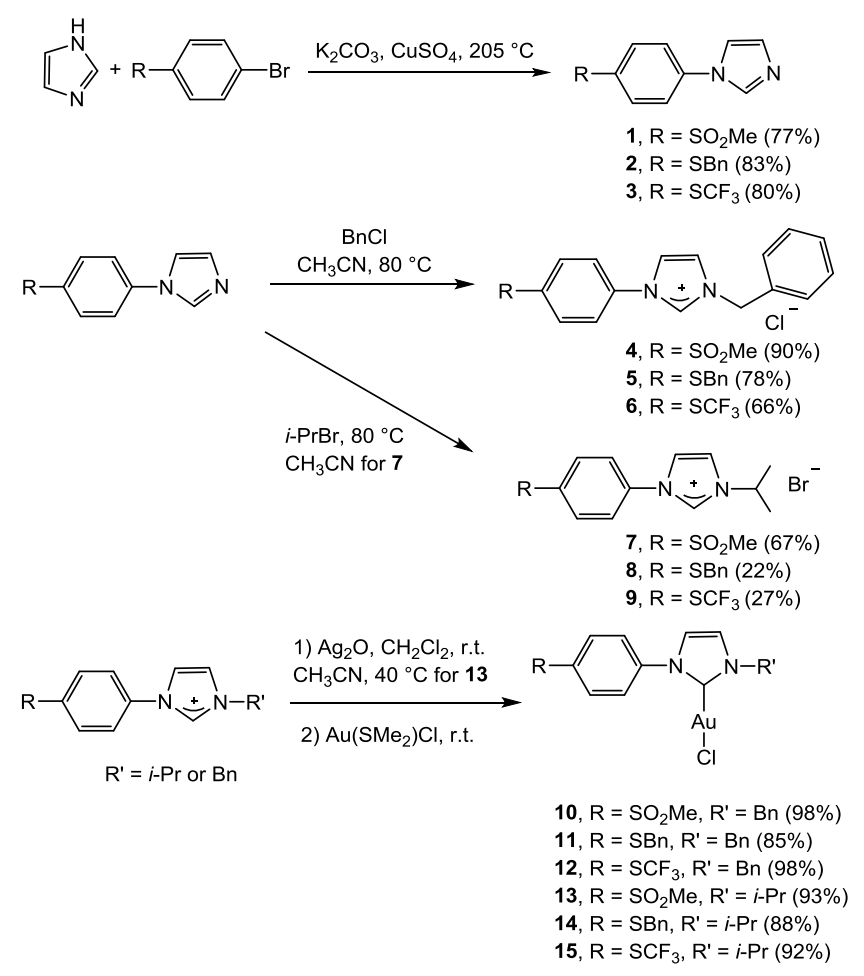

Scheme 1. Synthesis of imidazolium salts $4-9$ and gold(I) complexes 10-15 (yields are in brackets).

\section{Crystal structures of complexes 10 to 13 and 15.}

Crystals of 10, 11 and 15 have been obtained by slow diffusion of diethyl ether into a saturated solution of the corresponding complex in dichloromethane. In the case of 13 pentane has been used as counter-solvent and crystals of $\mathbf{1 2}$ have been obtained by slow evaporation of a saturated methanol solution of $\mathbf{1 2}$.

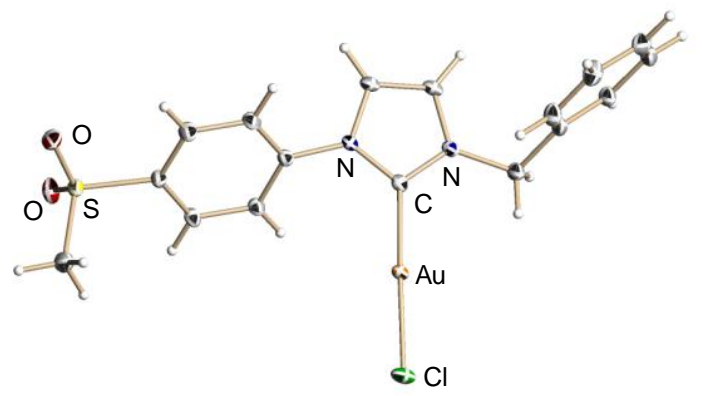


Figure 1: Structure of $\mathbf{1 0}$ depicted at a $50 \%$ thermal ellipsoid level. A non-coordinating solvent molecule has been omitted for clarity. Selected bond lengths $[\AA]$ and angles $\left[{ }^{\circ}\right]$ : Au-C 1.983(2), $\mathrm{Au}-\mathrm{Cl}$ 2.282(1), C-Au-Cl 177.89(5).

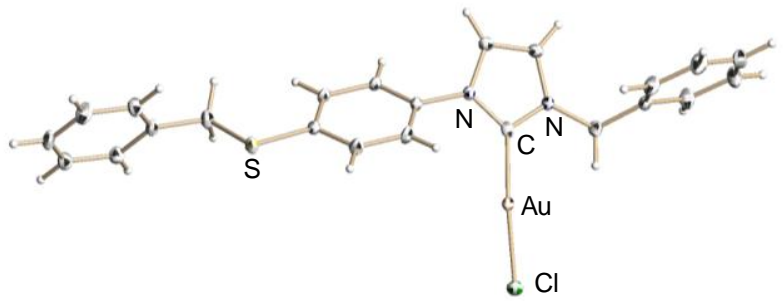

Figure 2: Structure of $\mathbf{1 1}$ depicted at a $50 \%$ thermal ellipsoid level. Selected bond lengths $[\AA]$ and angles $\left[^{\circ}\right]$ : Au-C 1.982(2), $\mathrm{Au}-\mathrm{Cl}$ 2.277(1), C-Au-Cl 175.37(7).

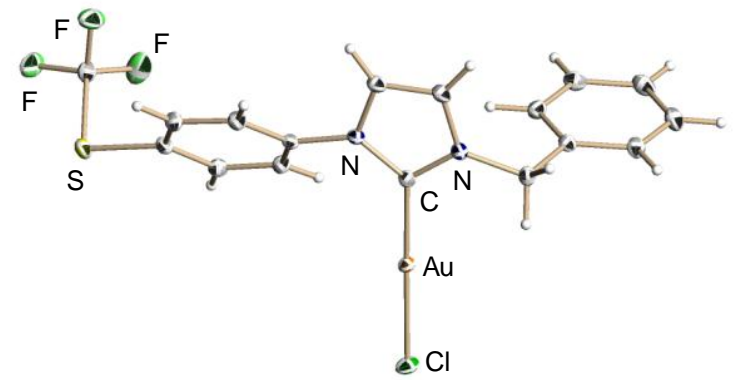

Figure 3: Structure of $\mathbf{1 2}$ depicted at a $50 \%$ thermal ellipsoid level. Selected bond lengths $[\AA]$ and angles $\left[{ }^{\circ}\right]$ : Au-C 1.976(2), Au-Cl 2.277(1), C-Au-Cl 177.55(5).

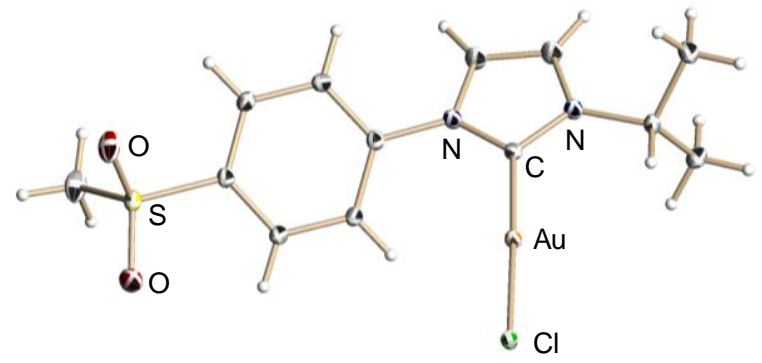

Figure 4: Structure of $\mathbf{1 3}$ depicted at a $50 \%$ thermal ellipsoid level. Selected bond lengths [̊] and angles [ $\left.{ }^{\circ}\right]$ : Au-C 1.988(2), $\mathrm{Au}-\mathrm{Cl}$ 2.324(1), C-Au-Cl 177.93(6).

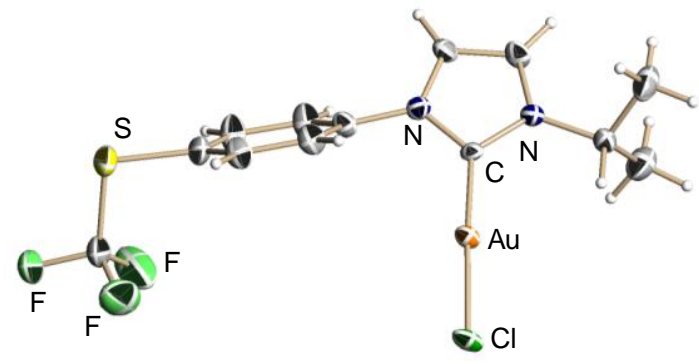

Figure 5: Structure of $\mathbf{1 5}$ depicted at a $50 \%$ thermal ellipsoid level. Selected bond lengths $[\AA]$ and angles $\left[{ }^{\circ}\right]$ : Au-C 1.981(7), $\mathrm{Au}-\mathrm{Cl}$ 2.302(3), C-Au-Cl 175.8(6).

Main features off all here presented structures are very similar; the gold carbon distances range from 1.97 to $1.99 \AA$, the gold chlorine distances from 2.27 to $2.30 \AA$, and the $\mathrm{C}-\mathrm{Au}-\mathrm{Cl}$ angles are very close to the expected linear coordination for gold(I) with values between 175 and $178^{\circ}$. Only complex $\mathbf{1 5}$ shows weak aurophilic interactions in the sold state with an Au-Au distance of $3.553 \AA$.

\section{Biological results:}

All imidazolium salts (4-9) and $\mathrm{Au}^{\mathrm{I}}(\mathrm{NHC}) \mathrm{Cl}$ complexes 1015 have been tested against the axenic amastigote form of $L$. infantum. Toxicity has been evaluated on human monocyte cell line THP1. Auranofin has been used as gold-containing control drug and amphotericin $\mathrm{B}$, miltefosine and pentamidine were used as antileishmanial compounds of reference. All results are presented in Table 1.

Table 1. In vitro antileishmanial activity and cytotoxicity of compounds 4-15.

\begin{tabular}{|c|c|c|c|}
\hline Compound & $\begin{array}{c}\text { L. infantum } \\
\text { axenic } \\
\text { amastigotes } \\
\mathrm{IC}_{50}(\mu \mathrm{M})^{\mathrm{a}}\end{array}$ & $\begin{array}{l}\text { THP1 } \\
\text { CC }_{50} \\
(\mu \mathrm{M})^{\mathrm{a}}\end{array}$ & $\begin{array}{l}\begin{array}{c}\text { Selectivity } \\
\text { index }\end{array} \\
\mathrm{CC}_{50} / \mathrm{IC}_{50}\end{array}$ \\
\hline 4 & $>143$ & & \\
\hline 5 & $8.24 \pm 0.15$ & $7.78 \pm 0.9$ & 0.94 \\
\hline 6 & $>134.47$ & & \\
\hline 7 & $>144.40$ & & \\
\hline 8 & $>128.09$ & & \\
\hline 9 & $>135.78$ & & \\
\hline 10 & $9.84 \pm 1.47$ & $59.65 \pm 7.48$ & 6.06 \\
\hline 11 & $1.30 \pm 0.05$ & $13.47 \pm 2.19$ & 10.36 \\
\hline 12 & $0.34 \pm 0.03$ & $15.84 \pm 2.86$ & 46.58 \\
\hline 13 & $9.33 \pm 1.81$ & $>100$ & $>11$ \\
\hline 14 & $0.35 \pm 0.07$ & $20.93 \pm 1.68$ & 59.8 \\
\hline 15 & $0.15 \pm 0.04$ & $16.24 \pm 3.27$ & 108.27 \\
\hline Auranofin ${ }^{b}$ & $0.07 \pm 0.01$ & $2.64 \pm 0.24$ & 37.71 \\
\hline Amphotericin $\mathbf{B}^{\mathbf{c}}$ & $0.06 \pm 0.01$ & $13.13 \pm 0.92$ & 218.83 \\
\hline Pentamidine $^{c}$ & $1.36 \pm 0.31$ & $65.87 \pm 7.49$ & 48.43 \\
\hline Miltefosine $^{c}$ & $0.46 \pm 0.04$ & $35.02 \pm 2.98$ & 76.13 \\
\hline Doxorubicin $^{d}$ & - & $0.83 \pm 0.07$ & - \\
\hline
\end{tabular}

${ }^{\mathrm{a}}$ Mean of three independent experiments.

${ }^{\mathrm{b}}$ Auranofin was used as a gold-based drug of reference.

${ }^{c}$ Amphotericin B, miltefosine and pentamidine were used as antileishmanial compounds of reference.

${ }^{\mathrm{d}}$ Doxorubicin was used as positive control of cytotoxicity.

As observed in previous studies, the precursors of the carbene ligands are either inactive with $\mathrm{IC}_{50}$ values higher than $100 \mu \mathrm{M}$ as in the case of $\mathbf{4}$ and $\mathbf{6}$ to $\mathbf{9}$, or they show some non- 
specific activity with selectivity indexes close to 1 , as in the case of proligand $\mathbf{5}$. In contrast to this, all here presented gold(I) complexes show moderate to good antileishmanial activity with SI's higher than 6 . The crucial role of gold cations is not limited to NHC ligands, the same phenomenon has been observed in the case of neutral thiolato-gold(I) complexes and cationic gold(I) complexes coordinated by thione group containing ligands. ${ }^{35-37}$ For such sulfur-containing gold(I) complexes $\mathrm{IC}_{50}$ values between 0.5 and $3.7 \mu \mathrm{M}$ for $L$. infantum amastigotes have been found. The corresponding SI values, in relation to THP1 cells, are in the range of 2 to 6 . In a previous study, we used a thionanisole substituted NHC ligand bearing either a benzyl group or a quinoline moiety, and the corresponding neutral $\mathrm{Au}^{\mathrm{l}}(\mathrm{NHC}) \mathrm{Cl}$ complexes showed $\mathrm{IC}_{50}$ values of 0.7 and $0.9 \mu \mathrm{M}$ for axenic amastigotes of $L$. infantum with SI's around 9 for both, based on the toxicity against J774A.1 cells. ${ }^{30}$ These here presented series focus on variations of sulfur-groups based on the thioanisole motif by replacing $\mathrm{SMe}$ by $\mathrm{SO}_{2} \mathrm{Me}, \mathrm{SBn}$ and $\mathrm{SCF}_{3}$. The $\mathrm{SO}_{2} \mathrm{Me}$ group bearing complexes 10 and 13 show the lowest positive effect against Leishmania, with $\mathrm{IC}_{50}$ values of 9.8 and $9.3 \mu \mathrm{M}$, respectively. This is going on with a low selectivity with SI's of 6 and 11 respectively. Complexes $\mathbf{1 0}$ and $\mathbf{1 3}$ show significantly lower activity and selectivity in comparison to all reference drugs tested in this study. Concerns the SBn group, complex 11 gives an $\mathrm{IC}_{50}$ of $1.3 \mu \mathrm{M}$, close to the activity of pentamidine, but with low selectivity $(\mathrm{SI}=10.4)$, five times lower than pentamidine. Isopropyl substituted $\mathbf{1 4}$ shows even better activity $\left(\mathrm{IC}_{50}=0.35 \mu \mathrm{M}\right)$ than miltefosine $\left(\mathrm{IC}_{50}=0.46 \mu \mathrm{M}\right)$, combined with a selectivity $(\mathrm{SI}=60)$ between miltefosine and pentamidine. The best results have been obtained using the $\mathrm{SCF}_{3}$ group (complexes 12 and 15). While complex 12 gives $\mathrm{IC}_{50}$ values $(0.34 \mu \mathrm{M})$ and selectivity $(\mathrm{SI}=46)$ very similar to complex 14, complex 15 shows values $\left(\mathrm{IC}_{50}=0.15 \mu \mathrm{M}\right.$ and SI $=108$ ) lying between the most active and selective reference drugs, namely miltefosine and amphotericin B. Concerning all here tested gold complexes, auranofin shows a lower $\mathrm{IC}_{50}$ than all here tested complexes, but accompanied by a high toxicity against THP1 leading to a lower selectivity than complexes 12, 14 and 15. Regarding the second substituent of the NHC ligand, the isopropyl group gives better activities and selectivity than benzyl, so the best result could be obtained with complex 15 combining $\mathrm{SCF}_{3}$ and isopropyl.

\section{CONCLUSION}

A family of six new imidazolium salts and their corresponding neutral $\mathrm{Au}^{\mathrm{I}}(\mathrm{NHC}) \mathrm{Cl}$ complexes has been synthesized and characterized. Five of the six gold complexes have been crystallized and analyzed by X-ray structure determination. All twelve new compounds have been studied on $L$. infantum axenic amastigotes for their antileishmanial properties and three of the gold complexes revealed good to very good antiamastigote activity combined with high selectivity in the same range as the reference drugs. Complexes 12, 14 and 15 could be promising candidates for the development of a new class of antileishmanial drugs and further mechanistical and in vivo studies are under investigation.

\section{EXPERIMENTAL SECTION}

\section{General Information:}

All complexation reactions were performed under an inert atmosphere of dry nitrogen by using standard vacuum line and Schlenk tube techniques. All reagents were used as received from commercial suppliers. Reactions involving silver compounds were performed with the exclusion of light. ${ }^{1} \mathrm{H}(300$ or $400 \mathrm{MHz}),{ }^{13} \mathrm{C}(75$ or $101 \mathrm{MHz})$ and ${ }^{19} \mathrm{~F}(282$ or $376 \mathrm{MHz}$ ) NMR spectra were recorded at $298 \mathrm{~K}$ on Bruker AV300 or Bruker AV400 spectrometers in $\mathrm{CDCl}_{3}, \mathrm{CD}_{3} \mathrm{CN}$ and DMSO- $d_{6}$ as solvents. Elemental analyses were carried out by the "Service de Microanalyse du Laboratoire de Chimie de Coordination (Toulouse)". HRMS were performed with a Thermo Finnigan MAT $95 \mathrm{XL}$ spectrometer using electrospray ionization (ESI) by the "Service de Spectrométrie de Masse de Chimie UPS-CNRS” (Toulouse).

\section{1-[4-(Methylsulfonyl)phenyl]-1H-imidazole (1)}

In a pressure flask, imidazole $(867.75 \mathrm{mg}, 12.75 \mathrm{mmol}), 1$-bromo-4(methylsulfonyl)benzene $(1.5 \mathrm{mg}, 6.37 \mathrm{mmol}), \mathrm{K}_{2} \mathrm{CO}_{3}(881.02 \mathrm{mg}$, $6.37 \mathrm{mmol}$ ) and a catalytic amount of $\mathrm{CuSO}_{4}$ were stirred at $205^{\circ} \mathrm{C}$ for $48 \mathrm{~h}$. After cooling to room temperature, the crude product was extracted with $\mathrm{MeOH}$, filtered and the solvent was evaporated under reduced pressure. The product was purified by column chromatography on silica gel with a mixture of $\mathrm{CH}_{2} \mathrm{Cl}_{2}$ and $\mathrm{MeOH}(90 / 10)$ as eluent to give a yellow solid $(1.09 \mathrm{~g}, 77 \%) .{ }^{1} \mathrm{H}$ NMR $(300 \mathrm{MHz}$, DMSO- $\left.d_{6}\right) \delta 8.45(\mathrm{dd}, J=1.4,0.8 \mathrm{~Hz}, 1 \mathrm{H}, \mathrm{H} 2), 8.09-8.03(\mathrm{~m}, 2 \mathrm{H}$, H8), 8.00-7.95 (m, 2H, H7), 7.92 (dd, $J=1.4 \mathrm{~Hz}, 1 \mathrm{H}, \mathrm{H} 5), 7.17$ (dd, $J=1.4,0.8 \mathrm{~Hz}, 1 \mathrm{H}, \mathrm{H} 4), 3.28\left(\mathrm{~s}, 3 \mathrm{H}, \mathrm{CH}_{3}\right) .{ }^{13} \mathrm{C}$ NMR $(100 \mathrm{MHz}$, $\left.\mathrm{CDCl}_{3}\right) \delta 141.4(1 \mathrm{C}, \mathrm{C} 2), 139.2$ (1C, C9), 135.4 (1C, C6), $131.6(1 \mathrm{C}$, C4), 129.7 (2C, C8), 121.4 (2C, C7), 117.7 (1C, C5), 44.6 (1C, $\mathrm{CH}_{3}$ ). HMRS $\left(\right.$ ES $\left.^{+}\right)$: Calc. For $\mathrm{C}_{10} \mathrm{H}_{11} \mathrm{~N}_{2} \mathrm{O}_{2} 223.0541$ found 223.0546 $\left[\mathrm{M}+\mathrm{H}^{+}\right]$.

\section{1-[4-(Benzylsulfanyl)phenyl]-1H-imidazole (2)}

In a pressure flask, imidazole $(229.25 \mathrm{mg}, 3.36 \mathrm{mmol}), 1$-bromo-4(benzylsulfanyl)benzene $(470.1 \mathrm{mg}, 1.68 \mathrm{mmol}), \mathrm{K}_{2} \mathrm{CO}_{3}(232.25 \mathrm{mg}$, $1.68 \mathrm{mmol}$ ) and a catalytic amount of $\mathrm{CuSO}_{4}$ were stirred at $205^{\circ} \mathrm{C}$ for $48 \mathrm{~h}$. After cooling to room temperature, the crude product was extracted with $\mathrm{MeOH}$, filtered and the solvent was evaporated under reduced pressure. The product was purified by column chromatography on silica gel with a mixture of $\mathrm{CH}_{2} \mathrm{Cl}_{2}$ and $\mathrm{MeOH}(90 / 10)$ as eluent to give a brown solid (370.9 $\mathrm{mg}, 83 \%$ yield). ${ }^{1} \mathrm{H}$ NMR (400 $\left.\mathrm{MHz}, \mathrm{CDCl}_{3}\right) \delta 7.82(\mathrm{~d}, J=1.5 \mathrm{~Hz}, 1 \mathrm{H}, \mathrm{H} 2), 7.39-7.20(\mathrm{~m}, 11 \mathrm{H}$, $\mathrm{H} 4, \mathrm{H} 5, \mathrm{H} 7, \mathrm{H} 8, \mathrm{H} 12, \mathrm{H} 13, \mathrm{H} 14), 4.15\left(\mathrm{~s}, 2 \mathrm{H}, \mathrm{CH}_{2}\right) .{ }^{13} \mathrm{C}$ NMR $(75$ $\left.\mathrm{MHz}, \mathrm{CDCl}_{3}\right) \delta 137.0(1 \mathrm{C}, \mathrm{C} 11), 135.8(1 \mathrm{C}, \mathrm{C} 2), 135.6(1 \mathrm{C}, \mathrm{C} 6)$, 135.5 (1C, C9), 131.1 (2C, C13), 130.5 (1C, C4), 128.8 (2C, C12), 128.6 (2C, C8), 127.4 (1C, C14), 121.7 (2C, C7), 118.1 (1C, C5), 39.1 (1C, C10). HMRS $\left(\mathrm{ES}^{+}\right)$: Calc. For $\mathrm{C}_{16} \mathrm{H}_{15} \mathrm{~N}_{2} \mathrm{~S} 267.0956$ found $267.0963\left[\mathrm{M}+\mathrm{H}^{+}\right]$.

\section{1-\{4-[(Trifluoromethyl)sulfanyl]phenyl $\}$ - $1 H$-imidazole (3)}

In a pressure flask, imidazole $(264.15 \mathrm{mg}, 3.88 \mathrm{mmol}), 1$-bromo-4(trifluoromethylsulfanyl)benzene $(500 \mathrm{mg}, 1.94 \mathrm{mmol}), \mathrm{K}_{2} \mathrm{CO}_{3}$ $(268.11 \mathrm{mg}, 1.94 \mathrm{mmol})$ and a catalytic amount of $\mathrm{CuSO}_{4}$ were stirred at $180{ }^{\circ} \mathrm{C}$ for $48 \mathrm{~h}$. After cooling to room temperature, the crude product was extracted with $\mathrm{MeOH}$, filtered and the solvent was evaporated under reduced pressure. The product was purified by column chromatography on silica gel with a mixture of $\mathrm{CH}_{2} \mathrm{Cl}_{2}$ and $\mathrm{MeOH}$ (90/10) as eluent to give a yellow solid (382.8 mg, $80 \%$ yield). ${ }^{1} \mathrm{H}$ NMR (400 MHz, CD $\left.{ }_{3} \mathrm{CN}\right) \delta 8.08-7.99(\mathrm{~m}, 1 \mathrm{H}, \mathrm{H} 2), 7.86-7.75(\mathrm{~m}$, 2H, H8), 7.67-7.57 (m, 2H, H7), 7.55-7.45 (m, 1H, H5), 7.21-7.12 $(\mathrm{m}, 1 \mathrm{H}, \mathrm{H} 4) .{ }^{13} \mathrm{C} \mathrm{NMR}\left(101 \mathrm{MHz}, \mathrm{CD}_{3} \mathrm{CN}\right) \delta 139.6$ (1C, C2), 138.0 (2C, C8), 135.7 (1C, C9), 130.5 (1C, C6), $129.8(1 \mathrm{C}, \mathrm{CF}$, q, J = $307.1 \mathrm{~Hz}), 121.8(1 \mathrm{C}, \mathrm{C} 4), 121.6$ (2C, C7), 117.3 (1C, C5). ${ }^{19} \mathrm{~F}$ NMR $\left(376 \mathrm{MHz}, \mathrm{CDCl}_{3}\right) \delta-42.70\left(3 \mathrm{~F}, \mathrm{CF}_{3}\right)$. HMRS $\left(\mathrm{ES}^{+}\right)$: Calc. For $\mathrm{C}_{10} \mathrm{H}_{8} \mathrm{~F}_{3} \mathrm{~N}_{2} \mathrm{~S} 245.0360$ found $245.0361\left[\mathrm{M}+\mathrm{H}^{+}\right]$.

\section{3-Benzyl-1-[4-(methylsulfonyl)phenyl]-1H-imidazol-3-ium chlo- ride (4)}

Under nitrogen atmosphere, 1 (250 mg, $1.12 \mathrm{mmol})$ and benzyl chloride $(0.14 \mathrm{~mL}, 1.22 \mathrm{mmol})$ were dissolved in dry $\mathrm{CH}_{3} \mathrm{CN}(10 \mathrm{~mL})$ and stirred at $80{ }^{\circ} \mathrm{C}$ for 5 days. The solvent was evaporated under reduced pressure, the residue was washed with ether and dried under vacuum to give a white solid (351 mg, 90\% yield). Anal. Calcd. For $\mathrm{C}_{17} \mathrm{H}_{17} \mathrm{ClN}_{2} \mathrm{O}_{2} \mathrm{~S}: \mathrm{C}, 58.53 ; \mathrm{H}, 4.91 ; \mathrm{N}, 8.03$; Found: C, 58.72, H, 4.83, $\mathrm{N}, 7.98 .{ }^{1} \mathrm{H}$ NMR $\left(400 \mathrm{MHz}, \mathrm{DMSO}-d_{6}\right) \delta 10.63(\mathrm{~d}, J=1.7 \mathrm{~Hz}, 1 \mathrm{H}$, H2), 8.53 (t, $J=1.9 \mathrm{~Hz}, 1 \mathrm{H}, \mathrm{H} 5), 8.25-8.10$ (m, 5H, H12, H13, H14), 
7.64-7.56 (m, 2H, H8), 7.49-7.36 (m, 3H, H4, H7), 5.60 (s, 2H $\mathrm{H} 10), 3.34\left(\mathrm{~s}, 3 \mathrm{H}, \mathrm{CH}_{3}\right) .{ }^{13} \mathrm{C}$ NMR $\left(101 \mathrm{MHz}, \mathrm{DMSO}-d_{6}\right) \delta 142.0$ (1C, C6), 138.8 (1C, C2), 136.9 (1C, C9), 134.9 (1C, C11), 129.4 (2C, C13), 129.4 (2C, C12), 129.3 (1C, C14), 129.1 (2C, C8), 123.9 (1C, C4), 123.2 (2C, C7), 122.0 (1C, C5), 52.8 (1C, C10), 43.7 (1C, $\left.\mathrm{CH}_{3}\right)$. HMRS $\left(\mathrm{ES}^{+}\right)$: Calc. For $\mathrm{C}_{17} \mathrm{H}_{17} \mathrm{~N}_{2} \mathrm{O}_{2} \mathrm{~S} 313.1011$ found $313.1014\left[\mathrm{M}^{-} \mathrm{Cl}^{-}\right]$.

\section{3-Benzyl-1-[4-(benzylsulfanyl)phenyl]-1H-imidazol-3-ium chlo- ride (5)}

Under nitrogen atmosphere, $2(100 \mathrm{mg}, 0.37 \mathrm{mmol})$ and benzyl chloride $(0.05 \mathrm{~mL}, 0.44 \mathrm{mmol})$ were dissolved in dry $\mathrm{CH}_{3} \mathrm{CN}(10 \mathrm{~mL})$ and stirred at $80{ }^{\circ} \mathrm{C}$ for 5 days. The solvent was evaporated under reduced pressure, the residue was washed with ether and dried under vacuum to give a yellow solid (113.5 $\mathrm{mg}, 78 \%$ yield). Anal. Calcd. For $\mathrm{C}_{23} \mathrm{H}_{21} \mathrm{ClN}_{2} \mathrm{~S}$ : C, 70.30; H, 5.39; N, 7.13; Found: C, 71.02, H, 5.14, N, 7.21. ${ }^{1} \mathrm{H}$ NMR $\left(300 \mathrm{MHz}, \mathrm{CDCl}_{3}\right) \delta 11.37$ (t, $\left.J=1.5 \mathrm{~Hz}, 1 \mathrm{H}, \mathrm{H} 2\right)$, $7.85(\mathrm{t}, J=1.8 \mathrm{~Hz}, 1 \mathrm{H}, \mathrm{H} 4), 7.69-7.54(\mathrm{~m}, 5 \mathrm{H}, \mathrm{H} 5, \mathrm{H} 7, \mathrm{H} 8), 7.34$ 7.12 (m, 10H, H12, H13, H14, H17, H18, H19), 5.71 (s, 2H, H15), 4.07 (s, 2H, H10). ${ }^{13} \mathrm{C}$ NMR (75 MHz, $\left.\mathrm{CDCl}_{3}\right) \delta 140.0$ (1C, C6), 136.2 (1C, C11), 135.8 (1C, C2), 133.2 (1C, C9), 132.0 (1C, C16), 129.8 (2C, C13), 129.4 (1C, C19), 129.4 (2C, C18), 129.3 (2C, C12), 128.8 (2C, C17), 128.7 (2C, C8), 127.5 ( 1C, C14), 122.8 (1C, C5), 121.9 (2C, C7), 120.6 (1C, C4), 53.5 (1C, C15), 37.9 (1C, C10). HMRS (ES ${ }^{+}$): Calc. For $\mathrm{C}_{23} \mathrm{H}_{21} \mathrm{~N}_{2} \mathrm{~S} 357.1425$ found 357.1428 [M-Cl']

\begin{abstract}
3-Benzyl-1-\{4-[(trifluoromethyl)sulfanyl $]$ phenyl $\}-1 H$-imidazol-3ium chloride (6)

Under nitrogen atmosphere, $3(130 \mathrm{mg}, 0.53 \mathrm{mmol})$ and benzyl chloride $(0.07 \mathrm{~mL}, 0.61 \mathrm{mmol})$ were dissolved in dry $\mathrm{CH}_{3} \mathrm{CN}(10 \mathrm{~mL})$ and stirred at $80{ }^{\circ} \mathrm{C}$ for 5 days. The solvent was evaporated under reduced pressure, the residue was washed with ether and dried under vacuum to give a white solid (130.3 mg, 66\% yield). Anal. Calcd. For $\mathrm{C}_{17} \mathrm{H}_{14} \mathrm{ClF}_{3} \mathrm{~N}_{2} \mathrm{~S}$ : C, 55.06; H, 3.81; N, 7.55; Found: C, 54.98, H, 3.88 , $\mathrm{N}, 7.51 .{ }^{1} \mathrm{H}$ NMR $\left(400 \mathrm{MHz}, \mathrm{CDCl}_{3}\right) \delta 11.61(\mathrm{t}, J=1.6 \mathrm{~Hz}, 1 \mathrm{H}, \mathrm{H} 2)$, $8.24(\mathrm{t}, J=1.9 \mathrm{~Hz}, 1 \mathrm{H}, \mathrm{H} 5), 8.04-7.92(\mathrm{~m}, 2 \mathrm{H}, \mathrm{H} 7), 7.73$ (t, $J=1.8$ $\mathrm{Hz}, 1 \mathrm{H}, \mathrm{H} 4), 7.72-7.64$ (m, 2H, H8), 7.61-7.46 (m, 2H, H12), 7.277.15 (m, 3H, H13, H14), 5.68 (s, 2H, H10). ${ }^{13} \mathrm{C}$ NMR $(101 \mathrm{MHz}$, $\left.\mathrm{CDCl}_{3}\right) \delta 137.9(2 \mathrm{C}, \mathrm{C} 8), 136.3(1 \mathrm{C}, \mathrm{C} 2), 136.1$ (1C, C9), $133.0(1 \mathrm{C}$ C6), 129.5 (1C, C11), 129.3 (2C, C7), 129.1 (2C, C13), 129.0 (1C, $\left.\mathrm{CF}_{3}, \mathrm{q}, \mathrm{J}=308.7 \mathrm{~Hz}\right), 126.6(1 \mathrm{C}, \mathrm{C} 4), 123.3(1 \mathrm{C}, \mathrm{C} 5), 122.4(2 \mathrm{C}$, C12), 121.1 (1C, C14), 53.4 (1C, C10). ${ }^{19} \mathrm{~F}$ NMR (376 MHz, $\mathrm{CDCl}_{3}$ ) $\delta-42.17\left(3 \mathrm{~F}, \mathrm{CF}_{3}\right)$. HMRS (ES $\left.{ }^{+}\right)$: Calc. For $\mathrm{C}_{17} \mathrm{H}_{14} \mathrm{~N}_{2} \mathrm{~F}_{3} \mathrm{~S} 335.0830$ found $335.0838\left[\mathrm{M}-\mathrm{Cl}^{-}\right]$.
\end{abstract}

\section{3-Isopropyl-1-(4-(methylsulfonyl)phenyl)-1H-imidazol-3-ium bromide (7)}

In a pressure flask, $1(200 \mathrm{mg}, 0.90 \mathrm{mmol})$ and 2-bromopropane (3 $\mathrm{mL}, 32 \mathrm{mmol}$ ) were dissolved in $\mathrm{CH}_{3} \mathrm{CN}(5 \mathrm{~mL})$ and stirred at $80{ }^{\circ} \mathrm{C}$ for one week. The solvent was evaporated under reduced pressure, the residue was washed with DCM and dried under vacuum to give a white solid (207.7 mg, 67\% yield). Anal. Calcd. For $\mathrm{C}_{13} \mathrm{H}_{17} \mathrm{BrN}_{2} \mathrm{O}_{2} \mathrm{~S}$ : C, 45.22; H, 4.96; N, 8.11; Found: C, 45.15, H, 5.01, N, 8.25. ${ }^{1} \mathrm{H}$ NMR (400 MHz, DMSO-d $\left.d_{6}\right) 10.06$ (s, 1H, H2), 8.49 (s, 1H, H4), 8.32-8.08 (m, 5H, H5, H7, H8), 4.76 (qq, $J=6.6 \mathrm{~Hz}, 1 \mathrm{H}, \mathrm{H} 10$ ), 3.34 (s, 3H, H12), $1.58(\mathrm{~d}, J=6.6 \mathrm{~Hz}, 6 \mathrm{H}, \mathrm{H} 11) .{ }^{13} \mathrm{C}$ NMR $(101 \mathrm{MHz}$ DMSO- $\left.d_{6}\right) \delta 141.9$ (1C, C6), 138.9 (1C, C9), 135.4 (1C, C2), 129.4 (2C, C8), 123.2 (2C, C7), 122.3 (1C, C5), 121.6 (1C, C4), 53.7 (1C, C10), 43.7 (1C, C12), 22.7 (2C, C11). HMRS $\left(\mathrm{ES}^{+}\right)$: Calc. For $\mathrm{C}_{13} \mathrm{H}_{17} \mathrm{~N}_{2} \mathrm{O}_{2} \mathrm{~S} 265.1011$ found 265.1008 [M-Br]

\section{1-(4-(Benzylthio)phenyl)-3-isopropyl-1H-imidazol-3-ium bromide} (8)

In a pressure flask, $2(100 \mathrm{mg}, 0.37 \mathrm{mmol})$ was dissolved in 2 bromopropane ( $3 \mathrm{~mL}, 32 \mathrm{mmol}$ ) and stirred at $80{ }^{\circ} \mathrm{C}$ for one week. The solvent was evaporated under reduced pressure, the residue was washed with ether and dried under vacuum to give a yellow solid (32.3 mg, 22\% yield). Anal. Calcd. For $\mathrm{C}_{19} \mathrm{H}_{21} \mathrm{BrN}_{2} \mathrm{~S}$ : C, 58.61; H, 5.44; N, 7.19; Found: C, 58.59, H, 5.39, N, 7.22. ${ }^{1} \mathrm{H}$ NMR $(300 \mathrm{MHz}$ $\left.\mathrm{CDCl}_{3}\right) \delta 11.13(\mathrm{~s}, 1 \mathrm{H}, \mathrm{H} 2), 7.91-7.63(\mathrm{~m}, 4 \mathrm{H}, \mathrm{H} 4, \mathrm{H} 5, \mathrm{H} 8), 7.45$ $7.36(\mathrm{~m}, 2 \mathrm{H}, \mathrm{H} 7), 7.33-7.22(\mathrm{~m}, 5 \mathrm{H}, \mathrm{C} 12, \mathrm{C} 13, \mathrm{C} 14), 5.27$ (qq, $J=$
$6.7 \mathrm{~Hz}, 1 \mathrm{H}, \mathrm{H} 15), 4.17$ (s, 2H, H10), 1.69 (d, $J=6.7 \mathrm{~Hz}, 6 \mathrm{H}, \mathrm{H} 16)$. ${ }^{13} \mathrm{C}$ NMR $\left(75 \mathrm{MHz}, \mathrm{CDCl}_{3}\right) \delta 140.1$ (1C, C6), 136.2 (1C, C11), 134.8 (1C, C2), 132.0 (1C, C9), 129.9 (2C, C13), 128.8 (2C, C12), 128.7 (2C, C8), 127.6 (1C, C14), 122.1 (2C, C7), 120.8 (1C,C4), 120.6 (1C, C5), 53.9 (1C, C15), 38.0 (1C, C10), 23.2 (2C, C16). HMRS (ES ${ }^{+}$: Calc. For $\mathrm{C}_{19} \mathrm{H}_{21} \mathrm{~N}_{2} \mathrm{~S} 309.1425$ found 309.1431 [M-Br]

3-Isopropyl-1-(4-((trifluoromethyl)thio)phenyl)-1H-imidazol-3ium bromide (9)

In a pressure flask, $3(125 \mathrm{mg}, 0.59 \mathrm{mmol})$, were dissolved in 2bromopropane $(3 \mathrm{~mL})$ and stirred at $80{ }^{\circ} \mathrm{C}$ one week, the solvent was evaporated under reduced pressure, and the solid washed with diethyl ether, and dried to have a yellow solid (58.2 mg, $27 \%$ yield). Anal. Calcd. For $\mathrm{C}_{13} \mathrm{H}_{14} \mathrm{BrF}_{3} \mathrm{~N}_{2} \mathrm{~S}$ : C, 42.52; H, 3.84; N, 7.63; Found: C, 42.41, H, 3.79, N, 7.68. ${ }^{1} \mathrm{H}$ NMR $\left(300 \mathrm{MHz}, \mathrm{CD}_{3} \mathrm{CN}\right) \delta 10.32$ (dt, $J=$ $1.8,0.9 \mathrm{~Hz}, 1 \mathrm{H}, \mathrm{H} 2), 8.13-8.01(\mathrm{~m}, 3 \mathrm{H}, \mathrm{H} 4, \mathrm{H} 7), 7.98-7.91(\mathrm{~m}, 2 \mathrm{H}$, H8), 7.88 (t, $J=1.9 \mathrm{~Hz}, 1 \mathrm{H}, \mathrm{H} 5), 4.89$ (qq, $J=6.7 \mathrm{~Hz}, 1 \mathrm{H}, \mathrm{H} 10), 1.65$ $(\mathrm{d}, J=6.7 \mathrm{~Hz}, 6 \mathrm{H}, \mathrm{H} 11) .{ }^{13} \mathrm{C}$ NMR $\left(75 \mathrm{MHz}, \mathrm{CD}_{3} \mathrm{CN}\right) \delta 137.8(2 \mathrm{C}$, C8), $137.2(1 \mathrm{C}, \mathrm{C} 2), 134.9$ (1C, C6), $129.6(\mathrm{q}, \mathrm{J}=307.2 \mathrm{~Hz}, 1 \mathrm{C}$, $\left.\mathrm{CF}_{3}\right), 125.6$ (1C, C9), 123.4 (2C, C7), 121.6 (1C, C4), 121.2 (1C, C5), $53.9(1 \mathrm{C}, \mathrm{C} 10), 22.0(2 \mathrm{C}, \mathrm{C} 11) .{ }^{19} \mathrm{~F}$ NMR $\left(282 \mathrm{MHz}, \mathrm{CD}_{3} \mathrm{CN}\right) \delta-$ $43.38\left(3 \mathrm{~F}, \mathrm{CF}_{3}\right)$. HMRS $\left(\mathrm{ES}^{+}\right)$: Calc. For $\mathrm{C}_{13} \mathrm{H}_{14} \mathrm{~F}_{3} \mathrm{~N}_{2} \mathrm{~S} 287.0830$ found 287.0830 [M-Br'].

\section{Complex 10}

Under nitrogen atmosphere, $(100 \mathrm{mg}, 0.28 \mathrm{mmol})$ of 4 and $(33.15 \mathrm{mg}$, $0.14 \mathrm{mmol}$ ) of $\mathrm{Ag}_{2} \mathrm{O}$ were dissolved in dry $\mathrm{CH}_{2} \mathrm{Cl}_{2}$, and stirred at r.t. for $18 \mathrm{~h}$. (90.72 mg, $0.31 \mathrm{mmol})$ of $\mathrm{Au}\left(\mathrm{SMe}_{2}\right) \mathrm{Cl}$ were added and stirred for $2 \mathrm{~h}$. The solution was filtered through a pad of celite and the solvent was removed under reduced pressure to give a white solid (150.5 mg, $98 \%$ yield). Anal. Calcd. For $\mathrm{C}_{17} \mathrm{H}_{16} \mathrm{AuClN}_{2} \mathrm{O}_{2} \mathrm{~S}$ : C, 37.41; H, 3.14; N, 5.13; Found: C, 37.74, H, 3.18, N, 5.17. ${ }^{1} \mathrm{H}$ NMR $\left(300 \mathrm{MHz}, \mathrm{DMSO}-d_{6}\right) \delta 8.20-8.12(\mathrm{~m}, 2 \mathrm{H}, \mathrm{H} 8), 8.12-8.05(\mathrm{~m}, 2 \mathrm{H}$, H7), 7.96 (d, $J=2.0 \mathrm{~Hz}, 1 \mathrm{H}, \mathrm{H} 5), 7.88(\mathrm{~d}, J=2.0 \mathrm{~Hz}, 1 \mathrm{H}, \mathrm{H} 4), 7.52$ 7.33 (m, 5H, H12, H13, H14), 5.51 (s, 2H, H10), 3.35 (s, 3H, CH $\mathrm{CH}_{3}$. ${ }^{13} \mathrm{C}$ NMR (101 MHz, DMSO-d $\left.d_{6}\right) \delta 169.3$ (1C, C2), 143.1 (1C, C6), 141.5 (1C, C9), 136.7 (1C, C11), 129.3 (2C, C13), 128.9 (2C, C12), 128.8 (1C, C14), 128.3 (2C, C8), 126.4 (2C, C7), 123.6 (1C, C4), 123.5 (1C, C5), $54.8(1 \mathrm{C}, \mathrm{C} 10), 43.7\left(1 \mathrm{C}, \mathrm{CH}_{3}\right)$. HMRS ( $\left.\mathrm{ES}^{+}\right)$: Calc. For $\mathrm{C}_{19} \mathrm{H}_{19} \mathrm{AuN}_{3} \mathrm{O}_{2} \mathrm{~S} 550.0863$ found $550.0873\left[\mathrm{M}-\mathrm{Cl}^{-}+\mathrm{CH}_{3} \mathrm{CN}\right]$

\section{Complex 11}

Under nitrogen atmosphere, $5(70 \mathrm{mg}, 0.18 \mathrm{mmol})$ and $(20.58 \mathrm{mg}$, $0.09 \mathrm{mmol}$ ) of $\mathrm{Ag}_{2} \mathrm{O}$ were dissolved in dry $\mathrm{CH}_{2} \mathrm{Cl}_{2}$, and stirred at r.t. for $18 \mathrm{~h}$. $(57.67 \mathrm{mg}, 0.19 \mathrm{mmol})$ of $\mathrm{Au}\left(\mathrm{SMe}_{2}\right) \mathrm{Cl}$ were added and stirred for $2 \mathrm{~h}$. The solution was filtered through a pad of celite and the solvent was removed under reduced pressure to give a white solid (88.9 mg, 85\% yield). Anal. Calcd. For $\mathrm{C}_{23} \mathrm{H}_{20} \mathrm{AuClN}_{2} \mathrm{~S}: \mathrm{C}, 46.91 ; \mathrm{H}$, 3.42 ; N, 4.76; Found: C, 46.92, H, 3.31, N, 4.72. ${ }^{1} \mathrm{H}$ NMR $(300 \mathrm{MHz}$, DMSO- $\left.d_{6}\right) \delta$ 7.83-7.77 (m, 2H, H4, H5), 7.70-7.64 (m, 2H, H7), 7.53-7.48 (m, 2H, H8), $7.45-7.20$ (m, 10H, H12, H13, H14, H17, H18, H19), 5.46 (s, 2H, H10), 4.35 (s, 2H, H15). ${ }^{13} \mathrm{C}$ NMR (101 MHz, DMSO- $\left.d_{6}\right) \delta 168.9$ (1C, C2), 138.2 (1C, C6), 137.4 (1C, C9), 136.8 (1C, C11), 136.8 (1C, C16), 129.3 (2C, C7), 129.3 (2C, C18), 128.9 (2C, C17), 128.7 (1C, C19), 128.6 (2C, C13), 128.2 (2C, C8), 127.7 (1C, C14), 125.9 (2C, C12), 123.5 (1C, C4), 123.0 (1C, C5), 54.6 (1C, C10), 36.5 (1C, C15). HMRS $\left(\mathrm{ES}^{+}\right)$: Calc. For $\mathrm{C}_{23} \mathrm{H}_{20} \mathrm{AuN}_{2} \mathrm{~S} 553.1013$ found 553.1014 [M-Cl'].

\section{Complex 12}

Under nitrogen atmosphere, $6(80 \mathrm{mg}, 0.22 \mathrm{mmol})$ and $(27.04 \mathrm{mg}$, $0.12 \mathrm{mmol}$ ) of $\mathrm{Ag}_{2} \mathrm{O}$ were dissolved in dry $\mathrm{CH}_{2} \mathrm{Cl}_{2}$, and stirred at r.t. for $18 \mathrm{~h}$. $(69.8 \mathrm{mg}, 0.24 \mathrm{mmol})$ of $\mathrm{Au}\left(\mathrm{SMe}_{2}\right) \mathrm{Cl}$ were added and stirred for $2 \mathrm{~h}$. The solution was filtered through a pad of celite and the solvent was removed under reduced pressure to give a white solid (119.8 mg, 98\% yield). Anal. Calcd. For $\mathrm{C}_{17} \mathrm{H}_{13} \mathrm{AuClF}_{3} \mathrm{~N}_{2} \mathrm{~S}$ : C, 35.96; H, 2.49; N, 4.93; Found: C, 36.05, H, 2.41, N, 4.92. ${ }^{1} \mathrm{H}$ NMR $(400$ $\left.\mathrm{MHz}, \mathrm{CD}_{3} \mathrm{CN}\right) \delta 7.88(\mathrm{~s}, 4 \mathrm{H}, \mathrm{H} 7, \mathrm{H} 8), 7.54-7.27(\mathrm{~m}, 7 \mathrm{H}, \mathrm{H} 4, \mathrm{H} 5$, $\mathrm{H} 12, \mathrm{H} 13, \mathrm{H} 14), 5.48$ (s, 2H, H10). ${ }^{13} \mathrm{C}$ NMR $\left(101 \mathrm{MHz}, \mathrm{CD}_{3} \mathrm{CN}\right) \delta$ 170.3 (1C, C2), 141.6 (1C, C6), 137.3 (2C, C13), 136.0 (1C, C11), $129.7\left(\mathrm{q}, \mathrm{J}=307.1 \mathrm{~Hz}, 1 \mathrm{C}, \mathrm{CF}_{3}\right), 128.9$ (2C, C8), 128.5 (1C, C9), 127.9 (2C, C12), 126.4 (2C, C7), 124.7 (1C, C14), 122.5 (1C, C5), 
122.3 (1C, C4), 54.6 (1C, C10). ${ }^{19} \mathrm{~F}$ NMR $\left(376 \mathrm{MHz}, \mathrm{CD}_{3} \mathrm{CN}\right) \delta-$ $43.37\left(3 \mathrm{~F}, \mathrm{C} F_{3}\right)$. HMRS $\left(\mathrm{ES}^{+}\right)$: Calc. For $\mathrm{C}_{19} \mathrm{H}_{16} \mathrm{AuF}_{3} \mathrm{~N}_{3} \mathrm{~S} 572.0683$ found $572.0682\left[\mathrm{M}-\mathrm{Cl}^{-}+\mathrm{CH}_{3} \mathrm{CN}\right]$.

\section{Complex 13}

Under nitrogen atmosphere, $7(50 \mathrm{mg}, 0.14 \mathrm{mmol})$ and $(16.64 \mathrm{mg}$, $0.07 \mathrm{mmol}$ ) of $\mathrm{Ag}_{2} \mathrm{O}$ were dissolved in dry $\mathrm{CH}_{3} \mathrm{CN}$, and stirred at 40 ${ }^{\circ} \mathrm{C}$ for $18 \mathrm{~h}$. (46.83 mg, $\left.0.16 \mathrm{mmol}\right)$ of $\mathrm{Au}\left(\mathrm{SMe}_{2}\right) \mathrm{Cl}$ were added and stirred for $2 \mathrm{~h}$. The solution was filtered through a pad of celite and the solvent was removed under reduced pressure to give a grey solid (67.3 mg, $93 \%$ yield). Anal. Calcd. For $\mathrm{C}_{13} \mathrm{H}_{16} \mathrm{AuClN}_{2} \mathrm{O}_{2} \mathrm{~S}: \mathrm{C}, 31.37$; $\mathrm{H}, 3.44$; N, 5.63; Found: C, 31.47, H, 3.48, N, 5.65. ${ }^{1} \mathrm{H}$ NMR (300 $\left.\mathrm{MHz}, \mathrm{DMSO}-d_{6}\right) \delta 8.18-8.11(\mathrm{~m}, 2 \mathrm{H}, \mathrm{H} 8), 8.11-8.02(\mathrm{~m}, 2 \mathrm{H}, \mathrm{H} 7)$, $7.96(\mathrm{~m}, 2 \mathrm{H}, \mathrm{H} 4, \mathrm{H} 5), 5.02(\mathrm{qq}, J=6.7 \mathrm{~Hz}, 1 \mathrm{H}, \mathrm{H} 10), 3.35$ (s, 3H, $\left.\mathrm{SCH}_{3}\right), 1.53(\mathrm{~d}, J=6.7 \mathrm{~Hz}, 6 \mathrm{H}, \mathrm{H} 11) .{ }^{13} \mathrm{C}$ NMR $\left(75 \mathrm{MHz}, \mathrm{DMSO}-d_{6}\right)$ $\delta 167.7$ (1C, C2), 143.3 (1C, C6), 141.4 (1C, C9), 128.9 (2C, C8), 126.3 (2C, C7), 123.4 (1C, C5), 120.0 (1C, C4), 54.7 (1C, C10), 43.7 (1C, $\left.\mathrm{SCH}_{3}\right), 23.1(2 \mathrm{C}, \mathrm{C} 11)$. HMRS $\left(\mathrm{ES}^{+}\right)$: Calc. For $\mathrm{C}_{15} \mathrm{H}_{19} \mathrm{AuN}_{3} \mathrm{O}_{2} \mathrm{~S}$ 502.0863 found $502.0866\left[\mathrm{M}-\mathrm{Cl}^{-}+\mathrm{CH}_{3} \mathrm{CN}\right]$.

\section{Complex 14}

Under nitrogen atmosphere, $8(34.6 \mathrm{mg}, 0.09 \mathrm{mmol})$ and $(11.58 \mathrm{mg}$, $0.05 \mathrm{mmol}$ ) of $\mathrm{Ag}_{2} \mathrm{O}$ were dissolved in dry $\mathrm{CH}_{2} \mathrm{Cl}_{2}$, and stirred at r.t. for $18 \mathrm{~h}$. (32.4 mg, $0.11 \mathrm{mmol})$ of $\mathrm{Au}\left(\mathrm{SMe}_{2}\right) \mathrm{Cl}$ were added and stirred for $2 \mathrm{~h}$. The solution was filtered through a pad of celite and the solvent was removed under reduced pressure to give a white solid (43 mg, $88 \%$ yield). Anal. Calcd. For $\mathrm{C}_{19} \mathrm{H}_{20} \mathrm{AuClN}_{2} \mathrm{~S}$ : C, 42.12; H, 3.91; $\mathrm{N}, 5.17$; Found: C, 42.03, H, 3.83, N, 5.21. ${ }^{1} \mathrm{H}$ NMR $(400 \mathrm{MHz}$, DMSO- $\left.d_{6}\right) \delta 7.89-7.83(\mathrm{~m}, 1 \mathrm{H}, \mathrm{H} 5), 7.80(\mathrm{~d}, J=2.1 \mathrm{~Hz}, 1 \mathrm{H}, \mathrm{H} 4)$, 7.70-7.60 (m, 2H, H7), 7.56-7.46 (m, 2H, H8), 7.43-7.39 (m, 2H, H12), 7.33 (m, 2H, H13), 7.28-7.23 (m, 1H, H14), 4.97 (qq, $J=6.9$ $\mathrm{Hz}, 1 \mathrm{H}, \mathrm{H} 15), 4.35(\mathrm{~d}, J=3.2 \mathrm{~Hz}, 2 \mathrm{H}, \mathrm{H} 10), 1.51(\mathrm{~d}, J=6.9 \mathrm{~Hz}, 6 \mathrm{H}$, H16). ${ }^{13} \mathrm{C}$ NMR (101 MHz, DMSO) $\delta 167.3$ (1C, C2), 138.1 (1C, C11), 137.4 (1C, C9), 137.1 (1C, C6), 129.3 (2C, C13), 128.9 (2C, C12), 128.6 (2C, C8), 127.7 (1C, C14), 125.9 (2C, C7), 123.4 (1C, C5), 119.4 (1C, C4), 54.3 (1C, C15), 36.6 (1C, C10), 23.2 (2C, C16). HMRS $\left(\mathrm{ES}^{+}\right)$: Calc. For $\mathrm{C}_{19} \mathrm{H}_{20} \mathrm{AuN}_{2} \mathrm{~S} 505.1013$ found 505.1013 [M$\left.\mathrm{Cl}^{-}\right]$.

\section{Complex 15}

Under nitrogen atmosphere, $9(47.7 \mathrm{mg}, 0.13 \mathrm{mmol})$ and $(14.79 \mathrm{mg}$, $0.064 \mathrm{mmol}$ ) of $\mathrm{Ag}_{2} \mathrm{O}$ were dissolved in dry $\mathrm{CH}_{2} \mathrm{Cl}_{2}$, and stirred at r.t. for $18 \mathrm{~h}$. (41.53 mg, $0.14 \mathrm{mmol})$ of $\mathrm{Au}\left(\mathrm{SMe}_{2}\right) \mathrm{Cl}$ were added and stirred for $2 \mathrm{~h}$. The solution was filtered through a pad of celite and the solvent was removed under reduced pressure to give a white solid (61.9 mg, $92 \%$ yield). Anal. Calcd. For $\mathrm{C}_{13} \mathrm{H}_{13} \mathrm{AuClF}_{3} \mathrm{~N}_{2} \mathrm{~S}: \mathrm{C}, 30.04$ H, 2.72; N, 5.39; Found: C, 30.17, H, 2.42, N, 5.45. ${ }^{1} \mathrm{H}$ NMR $(400$ $\left.\mathrm{MHz}, \mathrm{CDCl}_{3}\right) \delta 7.94-7.66(\mathrm{~m}, 4 \mathrm{H}, \mathrm{H} 7, \mathrm{H} 8), 7.27(\mathrm{~d}, J=2.1 \mathrm{~Hz}, 1 \mathrm{H}$, H5), $7.23(\mathrm{~d}, J=2.1 \mathrm{~Hz}, 1 \mathrm{H}, \mathrm{H} 4), 5.26(\mathrm{qq}, J=6.8 \mathrm{~Hz}, 1 \mathrm{H}, \mathrm{H} 10)$, $1.57(\mathrm{~d}, J=6.8 \mathrm{~Hz}, 6 \mathrm{H}, \mathrm{H} 11) .{ }^{13} \mathrm{C} \mathrm{NMR}\left(101 \mathrm{MHz}, \mathrm{CDCl}_{3}\right) \delta 169.5$ (1C, C2), 141.2 (1C, C9), 137.4 (2C, C8), 129.2 (q, J = 308.4 Hz, 1C, $\left.\mathrm{CF}_{3}\right), 125.7$ (2C, C7), 125.6 (1C, C6), 121.7 (1C, C5), 117.8 (1C, C4), 54.5 (1C, C10), $23.3(2 \mathrm{C}, \mathrm{C} 11) .{ }^{19} \mathrm{~F}$ NMR (376 MHz, $\left.\mathrm{CDCl}_{3}\right) \delta-42.11$ (3F, $\mathrm{C} F_{3}$ ). HMRS $\left(\mathrm{ES}^{+}\right)$: Calc. For $\mathrm{C}_{15} \mathrm{H}_{16} \mathrm{AuF}_{3} \mathrm{~N}_{3} \mathrm{~S} 524.0683$ found $524.0679\left[\mathrm{M}-\mathrm{Cl}^{-}+\mathrm{CH}_{3} \mathrm{CN}\right]$.

\section{Crystal data of 10 to 13 and 15:}

All data were collected at low temperature (100(2) K) using an oilcoated shock-cooled crystal on a Bruker-AXS APEX II diffractometer with $\mathrm{MoK} \alpha$ radiation $(\lambda=0.71073 \AA)$. The structure was solved by direct methods ${ }^{38}$ and all non-hydrogen atoms were refined anisotropic- ally using the least-squares method on $\mathrm{F}^{2}{ }^{39}$ The absolute structure of $\mathbf{1 5}$ has been refined. ${ }^{40}$

10: $\mathrm{C}_{17.5} \mathrm{H}_{17} \mathrm{AuCl}_{2} \mathrm{~N}_{2} \mathrm{O}_{2} \mathrm{~S}, \mathrm{Mr}=587.26$, crystal size $=0.40 \times 0.30 \mathrm{x}$ $0.30 \mathrm{~mm}^{3}$, triclinic, space group $P \overline{1}, a=9.537(1) \AA, b=9.696(1) \AA$, $c=12.554(2) \AA, \alpha=83.399(3)^{\circ}, \beta=73.612(2)^{\circ}, \gamma=61.558(2)^{\circ}, \mathrm{V}=$ 979.0(2) $\AA^{3}, \mathrm{Z}=2,28538$ reflections collected, 6772 unique reflections (Rint $=0.0290), \mathrm{R} 1=0.0161, \mathrm{wR} 2=0.0350[\mathrm{I}>2 \sigma(\mathrm{I})], \mathrm{R} 1=$ $0.0182, \mathrm{wR} 2=0.0356$ (all data) residual electron density $=1.132 \mathrm{e}^{-}$ 3 .
11: $\mathrm{C}_{23} \mathrm{H}_{20} \mathrm{AuClN} \mathrm{N}_{2} \mathrm{~S}, \mathrm{Mr}=588.89$, crystal size $=0.40 \times 0.20 \times 0.05$ $\mathrm{mm}^{3}$, monoclinic, space group $P 2{ }_{1} / c, a=10.188(1) \AA, b=17.565(2)$ $\AA, c=11.151(1) \AA, \beta=91.497(2)^{\circ}, \mathrm{V}=1994.8(3) \AA^{3}, \mathrm{Z}=4,33832$ reflections collected, 6328 unique reflections $($ Rint $=0.0430), \mathrm{R} 1=$ $0.0228, \mathrm{wR} 2=0.0502[\mathrm{I}>2 \sigma(\mathrm{I})], \mathrm{R} 1=0.0247, \mathrm{wR} 2=0.0510$ (all data), residual electron density $=1.340 \mathrm{e} \AA^{-3}$.

12: $\mathrm{C}_{17} \mathrm{H}_{13} \mathrm{AuClF}_{3} \mathrm{~N}_{2} \mathrm{~S}, \mathrm{Mr}=566.77$, crystal size $=0.40 \times 0.30 \times 0.30$ $\mathrm{mm}^{3}$, triclinic, space group $P \overline{1}, a=9.141(1) \AA, b=9.444(1) \AA, c=$ 10.147(1) $\AA, \alpha=92.716(2)^{\circ}, \beta=96.584(2)^{\circ}, \gamma=90.674(2)^{\circ}, \mathrm{V}=$ 869.0(1) $\AA^{3}, Z=2,29741$ reflections collected, 5512 unique reflections (Rint $=0.0388), \mathrm{R} 1=0.0151, \mathrm{wR} 2=0.0380[\mathrm{I}>2 \sigma(\mathrm{I})], \mathrm{R} 1=$ $0.0153, \mathrm{wR} 2=0.0381$ (all data), residual electron density $=1.524 \mathrm{e}$ $\AA^{-3}$.

13: $\mathrm{C}_{13} \mathrm{H}_{16} \mathrm{AuClN}_{2} \mathrm{O}_{2} \mathrm{~S}, \mathrm{Mr}=496.75$, crystal size $=0.40 \times 0.30 \times 0.30$ $\mathrm{mm}^{3}$, monoclinic, space group $P 2_{1} / c, a=11.876(1) \AA, b=16.723(2)$ $\AA, c=7.803(1) \AA, \beta=104.151(2)^{\circ}, \mathrm{V}=1502.5(2) \AA^{3}, \mathrm{Z}=4,28890$ reflections collected, 5369 unique reflections $($ Rint $=0.0392), \mathrm{R} 1=$ $0.0205, \mathrm{wR} 2=0.0544[\mathrm{I}>2 \sigma(\mathrm{I})], \mathrm{R} 1=0.0227, \mathrm{wR} 2=0.0556$ (all data), residual electron density $=2.740 \mathrm{e}^{-3}$.

15: $\mathrm{C}_{13} \mathrm{H}_{13} \mathrm{AuClF}_{3} \mathrm{~N}_{2} \mathrm{~S}, \mathrm{Mr}=518.73$, crystal size $=0.40 \times 0.10 \times 0.10$ $\mathrm{mm}^{3}$, monoclinic, space group $P 2_{1}, a=9.601(11) \AA, b=6.852(8) \AA$, $c=12.235(14) \AA, \beta=101.395(16)^{\circ}, \mathrm{V}=788.9(15) \AA^{3}, \mathrm{Z}=2,9402$ reflections collected, 4619 unique reflections $($ Rint $=0.0390), \mathrm{R} 1=$ $0.0311, \mathrm{wR} 2=0.0708[\mathrm{I}>2 \sigma(\mathrm{I})], \mathrm{R} 1=0.0361, \mathrm{wR} 2=0.0733$ (all data), absolute structure factor $x=-0.186(14)$, residual electron density $=1.494 \mathrm{e} \AA^{-3}$.

CCDC 2063045-2063049 contain the supplementary crystallographic data. These data can be obtained free of charge from The Cambridge Crystallographic Data Centre via www.ccdc.cam.ac.uk/data_request/cif.

\section{Antileishmanial evaluation}

Leishmania species used in this study were Leishmania infantum strain MHOM/MA/67/ITMAP-263 (CNR Leishmania, Montpellier, France) expressing luciferase activity. ${ }^{41}$

\section{Antileishmanial activity on axenic amastigotes}

$L$. Infantum promastigotes in logarithmic phase were centrifuged at $900 \mathrm{~g}$ for $10 \mathrm{~min}$, the supernatant was removed and replaced by the same volume of RPMI 1640 complete medium at pH 5.4 and incubated for $24 \mathrm{~h}$ at $24{ }^{\circ} \mathrm{C}$. Acidified promastigotes were then incubated for $24 \mathrm{~h}$ at $37{ }^{\circ} \mathrm{C}$ in a ventilated flask in humidified incubator with $5 \%$ $\mathrm{CO}_{2}$. Promastigotes were thus transformed into amastigotes in axenic conditions. ${ }^{42}$ The effects of the tested compounds on the growth of $L$. infantum axenic amastigotes were then assessed as follows. $L$. Infantum amastigotes were incubated at a density of $2.10^{6}$ parasites $/ \mathrm{mL}$ in sterile 96 -well plates with various concentrations of compounds dissolved in DMSO (final concentration less than $0.5 \% \mathrm{v} / \mathrm{v}$ ), in duplicate. Appropriate controls DMSO, amphotericin B, miltefosine and pentamidine were added to each set of experiments. To estimate the luciferase activity of axenic amastigotes, $80 \mu \mathrm{l}$ of each well are transferred to white 96-well plates, Steady Glow ${ }^{\circledR}$ reagent (Promega) was added according to manufacturer's instructions, and plates were incubated for $2 \mathrm{~min}$. The luminescence was measured in Microbeta Luminescence Counter (PerkinElmer). Inhibitory concentration $50 \%\left(\mathrm{IC}_{50}\right)$ was defined as the concentration of drug required to inhibit by $50 \%$ the metabolic activity of $L$. infantum amastigotes compared to control. $\mathrm{IC}_{50}$ values were calculated by non-linear regression analysis processed on dose-response curves, using TableCurve 2D V5 software. $\mathrm{IC}_{50}$ values represent the mean value calculated from three independent experiments.

\section{Cytotoxicity evaluation}

The evaluation of the compound cytotoxicity by MTT assay was done on THP-1 cell line (human monocyte). Briefly, cells $\left(0.77 .10^{5}\right.$ cells $/ \mathrm{mL}$ ) in $200 \mu \mathrm{L}$ of complete medium [RPMI 1640 supplemented with $10 \%$ fetal calf serum (FCS), $2 \mathrm{mM}$ L-glutamine and antibiotics (100 UI/mL penicillin and $100 \mu \mathrm{g} / \mathrm{mL}$ streptomycin)] + PMA (50 
$\mathrm{ng} / \mathrm{ml}$ ) were seeded into each well of 96-well plates and incubated at $37^{\circ} \mathrm{C}$ in a humidified $5 \% \mathrm{CO}_{2}$ with $95 \%$ air atmosphere. After a $96 \mathrm{~h}$ incubation, plates were rinse 3 times with medium and $100 \mu \mathrm{l}$ of medium were added. One hundred $\mu \mathrm{L}$ of medium with various compounds concentrations and appropriate controls were then added and the plates were incubated for $72 \mathrm{~h}$ at $37{ }^{\circ} \mathrm{C}$. The medium was then aspirated from the wells. MTT solution $(100 \mu \mathrm{L}$ of $0.5 \mathrm{mg} / \mathrm{mL}$ in RPMI) were then added to each well. Cells were incubated for $2 \mathrm{~h}$ at $37{ }^{\circ} \mathrm{C}$. MTT solution was then removed and DMSO $(100 \mu \mathrm{L})$ was added to dissolve the resulting formazan crystals. Plates were shaken vigorously ( $300 \mathrm{rpm}$ ) for $5 \mathrm{~min}$. The absorbance was measured at 570 $\mathrm{nm}$ with a microplate spectrophotometer (BIO-TEK ELx808 Absorbance Microplate Reader). DMSO was used as blank and doxorubicin (Sigma Aldrich) as positive control. $\mathrm{CC}_{50}$ were calculated by nonlinear regression analysis processed on dose-response curves, using TableCurve 2D V5 software.

\section{ASSOCIATED CONTENT}

\section{Supporting Information}

The Supporting Information is available free of charge on the ACS Publications website.

The supporting information contains the ${ }^{1} \mathrm{H},{ }^{13} \mathrm{C}$ and ${ }^{19} \mathrm{~F}$ NMR spectra related to compounds $\mathbf{4}$ to $\mathbf{1 5}$ as PDF file.

\section{AUTHOR INFORMATION}

\section{Corresponding Author}

* E-mail: hemmert@1cc-toulouse.fr, alexis.valentin@univ-tlse3.fr and gornitzka@1cc-toulouse.fr

Notes

The authors declare no competing financial interests.

\section{ACKNOWLEDGMENT}

This work was supported by the Centre National de la Recherche Scientifique (CNRS) and the Université des Sciences et de la Technologie d'Oran Mohamed Boudiaf.

\section{REFERENCES}

(1) www.who.int/neglected_diseases/diseases/en/ (Oct. 2018)

(2) Hendrickx, G.; Lancelot, R. A perspective on emerging mosquito and phlebotomine-borne diseases in Europe. Euro Surveill. 2010, 15(10), 19503.

(3) Serafim, T. D.; Iniguez, E.; Oliveira, F. Leishmania infantum. Trends Parasitol. 2020, 36(1), 80-81.

(4) Lievin-Le Moal, V.; Loiseau, P. M. Leishmania hijacking of the macrophage intracellular compartments. FEBS Journal 2016, 283, 598-607.

(5) Zulfiqar, B.; Shelper, T. B.; Avery, V. M. Leishmaniasis drug discovery: recent progress and challenges in assay development. Drug Discov. Today 2017, 22(10), 1516-1531.

(6) Carnielli, J. B. T.; Crouch, K.; Forrester, S.; Silva, V. C.; Carvalho, S. F. G.; Damasceno, J. D.; Brown, E.; Dickens, N. J.; Costa, D. L.; Costa, C. H. N.; Dietze, R.; Jeffares, D. C.; Mottram, J. C. A Leishmania infantum genetic marker associated with miltefosine treatment failure for visceral leishmaniasis. EBioMedicine 2018, 36, 83-91.

(7) E. Alessio, Bioinorganic Medicinal Chemistry, Wiley-VCH Verlag \& Co., Germany, 2011.

(8) Caballero, A. B.; Rodriguez-Dieguez, A.; Quiros, M.; Salas, J. M.; Huertas, O.; Ramirez-Macias, I.; Olmo, F.; Marin, C.; ChavesLemaur, G.; Gutierrez-Sanchez, R.; Sanchez-Moreno, M Triazolopyrimidine compounds containing first-row transition metals and their activity against the neglected infectious Chagas disease and leishmaniasis. Eur. J. Med. Chem. 2014, 85, 526-534.
(9) Rauf, M. K.; Yaseen, S.; Badshah, A.; Zaib, S.; Arshad, R.; Imtiaz Ud, D.; Tahir, M. N.; Iqbal, J. Synthesis, characterization and urease inhibition, in vitro anticancer and antileishmanial studies of $\mathrm{Ni}(\mathrm{II})$ complexes with $\mathrm{N}, \mathrm{N}, \mathrm{N}^{\prime}$-trisubstituted thioureas. J. Biol. Inorg. Chem. 2015, 20(3), 541-554.

(10) Yaseen, S.; Rauf, M. K.; Zaib, S.; Badshah, A.; Tahir, M. N.; Ali, M. I.; Imtiaz Ud, D.; Shahid, M.; Iqbal, J. Synthesis, characterization and urease inhibition, in vitro anticancer and antileishmanial studies of $\mathrm{Co}(\mathrm{III})$ complexes with N,N,N'-trisubstituted acylthioureas. Inorg. Chim. Acta 2016, 443, 69-77.

(11) Kaur, S.; Sachdeva, H.; Dhuria, S.; Sharma, M.; Kaur, T. Antileishmanial effect of cisplatin against murine visceral leishmaniasis. Parasitol. Int. 2010, 59, 62-69.

(12) Akhtari, J.; Faridnia, R.; Kalani, H.; Bastani, R.; Fakhar, M.; Rezvan, H.; Beydokhti, A. K. Potent in vitro antileishmanial activity of a nanoformulation of cisplatin with carbon nanotubes against Leishmania major. J. Glob. Antimicrob. Resist. 2019, 16, 11-16.

(13) Mbongo, N.; Loiseau, P. M.; Lawrence, F.; Bories, C.; Craciunescu, G.; Robert-Gero, M. In vitro sensitivity of Leishmania donovani to organometallic derivatives of pentamidine., Parasitol. Res. 1997, 83, 515-517.

(14) Navarro, N.; Visbal, G.; Marchán, E. in: Pérez Martin, J. M. (Ed.), Programmed Cell Death in Protozoa, Landes Bioscience and Springer, New York, 2008, 59-73.

(15) Caballero, A. B.; Salas, J. M.; Sánchez-Moreno, M. in: Metalbased Therapeutics for Leishmaniasis. IntechOpen 2014, 1-28.

(16) Tahghighi, A. Importance of metal complexes for development of potential leishmanicidal agents. J. Organomet. Chem. 2014, 770, 51-60.

(17) for review see: Ravera, M.; Moreno-Viguri, E.; Paucar, R.; Pérez-Silanes, S.; Gabano, E. Organometallic compounds in the discovery of new agents against kinetoplastid-caused diseases. Eur. $J$. Med. Chem. 2018, 155; 459-482.

(18) Navarro, M.; Cisneros-Fajardo, E. J.; Sierralta, A.; FernándezMestre, M.; Silva, P.; Arrieche, D.; Marchán, E. Design of copper DNA inter-calators with leishmanicidal activity. J. Biol. Inorg. Chem. 2003, 8, 401-408.

(19) Navarro, M.; Cisneros-Fajardo, E. J.; Fernández-Mestre, M.; Arrieche, D.; Marchán, E. Synthesis, characterization, DNA binding study and biological activity against Leishmania mexicana of $\left[\mathrm{Cu}(\mathrm{dppz})_{2}\right] \mathrm{BF}_{4}$. J. Inorg. Biochem. 2003, 97, 364-369.

(20) Navarro, M.; Cisneros-Fajardo, E. J.; Marchán, E. New Silver Polypyridyl Complexes: Synthesis, Characterization and Biological Activity on Leishmania Mexicana. Arzneim. Forsch./Drug Res. 2006, $56,600-604$.

(21) Navarro, M.; Hernández, C.; Colmenares, I.; Hernández, P.; Fernández, M.; Sierraalta, A.; Marchán, E. Synthesis and characterization of $\left[\mathrm{Au}(\mathrm{dppz})_{2}\right] \mathrm{Cl}_{3}$. DNA interaction studies and biological activity against Leishmania (L) Mexicana. J. Inorg. Biochem. 2007, $101,111-116$

(22) Minori, K.; Rosa, L. B.; Bonsignore, R.; Casini, A.; Miguel, D. C. Comparing the Antileishmanial Activity of Gold(I) and Gold(III) Compounds in L. amazonensis and L. braziliensis in Vitro. ChemMedChem. 2020, 15(22), 2146-2150.

(23) Rosa, L. B.; Aires, R. L.; Oliveira, L. S.; Fontes, J. V.; Miguel, D. C.; Abbehausen, C. A "Golden Age" for the discovery of new antileishmanial agents: Current status of leishmanicidal gold complexes and prospective targets beyond the trypanothione system. ChemMedChem. 2021, in press https://doi.org/10.1002/cmdc.202100022.

(24) Dumas, C.; Ouellette, M.; Tovar, J.; Cunningham, M. L.; Fairlamb, A. H.; Tamar, S.; Olivier, M. Disruption of the trypanothione reductase gene of Leishmania decreases its ability to survive oxidative stress in macrophages. EMBO J. 1997, 16, 25902598.

(25) Ilari, A.; Baiocco, P.; Messori, L.; Fiorillo, A.; Boffi, A.; Gramiccia, M.; Di Muccio, T.; Colotti, G. A gold-containing drug against parasitic polyamine metabolism: the X-ray structure of trypanothione reductase from Leishmania infantum in complex with auranofin reveals a dual mechanism of enzyme inhibition. Amino Acids 2012, 42, 803-811. 
(26) Baiocco, P.; Colotti, G.; Franceschini, S.; Ilary, A. Molecular Basis of Antimony Treatment in Leishmaniasis. J. Med. Chem. 2009, 52, 2603-2612.

(27) Hemmert, C.; Fabié, A.; Fabre, A.; Benoit-Vical, F.; Gornitzka, H. Synthesis, structures, and antimalarial activities of some silver(I), gold(I) and gold(III) complexes involving N-heterocyclic carbene ligands. Eur. J. Med. Chem. 2013, 60, 64-75.

(28) Boselli, L.; Ader, I.; Carraz, M.; Hemmert, C.; Cuvillier, O.; Gornitzka, H. Synthesis, structures, and selective toxicity to cancer cells of gold(I) complexes involving N-heterocyclic carbene ligands. Eur. J. Med. Chem. 2014, 85, 87-94.

(29) Hemmert, C.; Ramadani, A. P.; Boselli, L.; Fernández Álvarez, Á.; Paloque, L.; Augereau, J. M.; Gornitzka, H.; Benoit-Vical, F. Antiplasmodial activities of gold(I) complexes involving functionalized N-heterocyclic carbenes. Bioorg. Med. Chem. 2016, 24, 30753082.

(30) Zhang, C.; Bourgeade Delmas, S.; Fernández Álvarez, Á.; Valentin, A.; Hemmert, C.; Gornitzka, H. Synthesis, characterization, and antileishmanial activity of neutral N-heterocyclic carbenes gold(I) complexes. Eur. J. Med. Chem. 2018, 143, 1635-1643.

(31) Paloque, L.; Hemmert, C.; Valentin, A.; Gornitzka, H. Synthesis, characterization, and antileishmanial activities of gold(I) complexes involving quinoline functionalized $\mathrm{N}$-heterocyclic carbenes. Eur. J. Med. Chem. 2015, 94, 22-29.

(32) Zhang, C.; Maddelein, M. L.; Wai-Yin Sun, R.; Gornitzka, H.; Cuvillier, O.; Hemmert, C. Pharmacomodulation on Gold-NHC complexes for anticancer applications - is lipophilicity the key point? Eur. J. Med. Chem. 2018, 157, 320-332.

(33) Zhang, C.; Hemmert, C.; Gornitzka, H.; Cuvillier, O.; Zhang, M.; Sun, R. W. Cationic and Neutral N-Heterocyclic Carbene Gold(I) Complexes: Cytotoxicity, NCI-60 Screening, Cellular Uptake, Inhibition of Mammalian Thioredoxin Reductase, and Reactive Oxygen Species Formation. ChemMedChem 2018, 13, 1218-1229.

(34) Zhang, C.; Fortin, P.-Y.; Barnoin, G.; Qin, X.; Wang, X.; Fernandez Alvarez, A.; Bijani, C.; Maddelein, M.-L.; Hemmert, C.; Cuvillier, O.; Gornitzka, H. An Artemisinin-Derivative(NHC)Gold(I) Hybrid with Enhanced Cytotoxicity through Inhibition of NRF2 Transcriptional Activity. Angew. Chem. Int. Ed. 2020, 59, 12062-12068.
(35) Chaves, J. D. S.; Tunes, L. G.; de J. Franco, C. H.; Martins Francisco T.; Cimini Correa, C. C.; Murta, S. M. F.; do Monte-Neto, R. L.; Silva, H.; Fontes, A. P. S.; de Almeida, M. V. Novel gold(I) complexes with 5-phenyl-1,3,4-oxadiazole-2-thione and phosphine as potential anticancer and antileishmanial agents. Eur. J. Med. Chem. 2017, 127, 727-739.

(36) Tunes, L. G.; Morato, R. E.; Garcia, A.; Schmitz, V.; Steindel, M.;

Corrêa-Junior, J. D.; Dos Santos, H. F.; Frézard, F.; de Almeida, M. V.; Silva, H.; Moretti, N. S.; de Barros, A. L. B.; do Monte-Neto, R. L. Preclinical Gold Complexes as Oral Drug Candidates to Treat Leishmaniasis Are Potent Trypanothione Reductase Inhibitors. ACS Infect. Dis. 2020, 6, 1121-1139.

(37) Villaseñor Espinosa, A.; de Souza Costa, D.; Tunes, L. G.; do Monte-Neto, R. L.; Grazul, R. M.; de Almeida, M. V.; Silva, H. Anticancer and antileishmanial in vitro activity of gold(I) complexes with 1,3,4-oxadiazole-2 $(3 \mathrm{H})$-thione ligands derived from $\delta$-Dgluconolactone. Chem Biol Drug Des. 2021, 97, 41-50.

(30) Sheldrick, G. M. A short history of SHELX. Acta Cryst. 2008, A64, 112-122.

(31) Sheldrick, G. M. Crystal structure refinement with SHELXL. Acta Cryst. 2015, C71, 3-8.

(32) Parsons, S.; Flack, H. D.; Wagner, T. Use of intensity quotients and differences in absolute structure refinement. Acta Cryst. 2013, B69, 249-259.

(33) Sereno, D.; Roy, G.; Lemesre, J. L.; Papadopoulou, B.; Ouellette, M. DNA Transformation of Leishmania Infantum Axenic Amastigotes and Their Use in Drug Screening. Antimicrob. Agents. Chemother. 2001, 45(4), 1168-1173.

(34) Paloque, L.; Perez-Berezo, T.; Abot, A.; Dalloux-Chioccioli, J.; Bourgeade-Delmas, S.; Le Faouder, P.; Pujo, J.; Teste, M.-A.; François, J.-M.; Schebb, N. H.; Mainka, M.; Rolland, C.; Blanpied, C.; Dietrich, G.; Bertrand-Michel, J.; Deraison, C.; Valentin, A.; Cenac, N. Polyunsaturated fatty acid metabolites: biosynthesis in Leishmania and role in parasite/host interaction. J. Lipid Res. 2019, $60(3), 636-647$

Authors are required to submit a graphic entry for the Table of Contents (TOC) that, in conjunction with the manuscript title, should give the reader a representative idea of one of the following: A key structure, reaction, equation, concept, or theorem, etc., that is discussed in the manuscript. Consult the journal's Instructions for Authors for TOC graphic specifications.

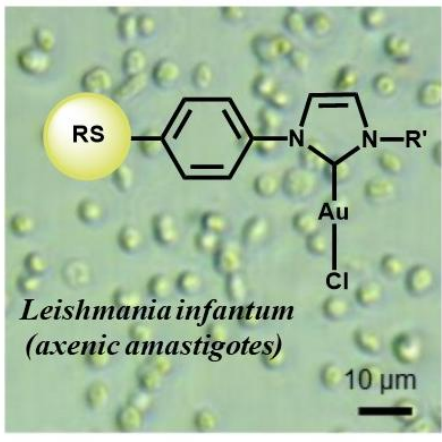

